\title{
Human Nature and Sharing: Reflection on the Education of Chinese Citizens under the Background of Shared Economy
}

\author{
Shizhan Liu', a, Xiaoli Lin", b and Jiqing Pan², c \\ ${ }^{1}$ School of Tianjin University of Technology, Tianjin 300384, China; \\ ${ }^{2}$ School of Tianjin University of Technology, Tianjin 300384, China. \\ ashizhanziwo@163.com, b718993900@qq.com, cjqpan@163.com
}

Keywords: Sharing economy, Contradiction, Civic education and reflection.

\begin{abstract}
Sharing the single car, sharing the car, sharing the charge treasure and so on is a shared economy under the guidance of the concept of shared development, new mode of economic operation, which emerges as the times require of the present society. As the mirror of sharing a bicycle refracted, there are also many contradictions in the process of developing the shared economy with the distinct characteristics of the times. In addition to the formulation and improvement of relevant laws and regulations, strengthen the supervision of the market operation, what is the solution to the problem of the cure of the medicine, which once again led to our thinking of civic education.
\end{abstract}

\section{Introduction}

On the Communist Party of China in the fifth Plenary Session of the 18th CPC Central Committee the party central leadership, represented by general secretary Jinping Xi, has put forward five major development concepts of "innovation, coordination, green, open and sharing". The shared economy, represented by sharing a single car, sharing a car, sharing a rechargeable treasure, is under the guidance of the concept of shared development, a new mode of economic operation, which emerges as the times require of the present society, As the famous economist, sharing "zero marginal cost to society" author Jeremy Rifkin proposed: "sharing economy has brought a change in life style of human resources revolution, it brings the economic life of the new organization, will go beyond the traditional market model", the shared economy breaks through the traditional economic model and separations the ownership of the goods from the right to use, and forms the situation of the ownership and the private ownership of the right to use.

\section{What has been reflected in the sharing of a bicycle}

From the stage of socialist development, the principal contradiction in our society is still the people's growing material and cultural needs contradiction between the backward social productive forces, also shared economic development to a certain material development level as the basis, but also to the public moral field put forward higher requirements. As the mirror of a shared bicycle is refracted, there are also many contradictions in the process of developing the shared economy with the distinct characteristics of the times. There are contradictions between self - use and common contradiction, self-discipline and heteronomy, as well as the contradiction between egoism and altruism. Self-discipline refers to the ability of a person to consciously restrain his own behavior heteronomy refers to the external binding force on human behavior, such as laws and regulations or the guidance of public opinion. In real life or to the individual of a citizen, people are more accustomed to heteronomy, that is, what we usually say is free from prohibition, because laws and regulations are usually required only for the lower limits of people's behavior, sharing is a highly moral behavior, have a certain degree of freedom. Therefore, heteronomy has some limitations in the norms of shared behavior. The development of shared economy requires people to change from customary heteronomy to self-discipline and improve their moral level, take the initiative to build a good shared ecological atmosphere. Egoism is human, and altruistic consciousness is the embodiment of spiritual civilization. But what many people don't realize is in the shared economy, egoism and 
altruism have unity, because we choose to participate in the sharing, the formation of a community of interests, the damage to the shared environment is equivalent to increasing the cost of sharing, indirect damage to its own interests. In the process of sharing, it's not just things that people share, as things are shared, there is a common value orientation, sharing strengthens connections between individuals, it also strengthens the individual's identity to the collective, every individual is concerted in the collective. So, the lack of shared spirit reflected by the development of the shared economy, raising the moral level of the individual to the individual, the strengthening of the common spiritual belief and national cohesion of a nation, there is a neglecting influence. Contradictions in the process of shared economic development, taking the shared bike as an example, policy designers often overestimate human nature sometimes when formulating corresponding rules, as some experts point out, in the process of transforming the acquaintances society like a stranger's society, contra bonus mores, from the past, the price of personal reputation, the accusation from the surrounding, it has become a rule that is bound by the rule of law and the system of honesty and credit. This means that, In the unripe areas of the legal system and the integrity system, we can choose to be a "guard" or "saboteurs". Clearly, shared economy, represented by sharing a single car, has become a prism that reflects the moral quality of citizens, sharing the trust based on each other and the natural binding force of each person from the heart, facing these problems, in addition to the formulation and improvement of the relevant laws and regulations, strengthen the regulation of market operation, the flow and sharing of resources in the whole society is based on the general high level of national quality, what is so common is not the benefit group of a shared economic policy or the majority of the society, what is the cure for the problem, this once again led to our thinking about civic education.

The word "Civic Education" was first proposed by the ancient Greek philosopher Aristotle. Early twentieth Century, Kay Sing Steiner, the German educator, believes that school education is developed for the development of citizens useful to the country. Civic education has thus become an educational process for the citizens of the western society to cultivate a high sense of social responsibility and to contribute to the development of the country and society. "Civic Education" has two concepts in broad sense and narrow sense. A broad sense of civic education is a modern country that uses various means and methods to promote citizens to form a correct understanding of the role, the educational process that makes it a qualified citizen for the needs of the state and society. In a narrow sense, civic education refers to the citizenship course that imparted knowledge and skills of citizenship.

\section{The core of Rousseau's civic education thought}

Rousseau was a great French thinker, philosopher, educator and writer in the eighteenth Century, the thought pioneer of the French Revolution in eighteenth Century, an outstanding Democrat and the founder of the romantic literary genre, one of the most outstanding representatives of the enlightenment. Its representative works are On the origin and foundation of human inequality, The theory of social contract, Emile, The Confessions, The New Heloise etc. Rousseau has a famous saying "I am convinced that only moral citizens can give their homeland an acceptable salute." His ideas of naturalism, moral citizenship and free citizenship education based on the establishment of a state community, the educational thought of the natural man, Rousseau, thinks that, the purpose of education is to cultivate "natural people", It is a generation of people who are fully free of growth, coordinated development of body and mind, capable of self-reliance, free from traditional constraints, and capable of adapting to social life. Rousseau's ideology of moral citizenship education is closely related to his political philosophy, he advocated the establishment of a country with a good social order through the social contract. The premise of all this is to cultivate citizens of good quality, as a representative of the New Republicanism, the central issue of his concern is the problem of human alienation in modern society, that is, the education of man as a natural person and the divisive problem of civic education as a common obligation. This plight of self-splitting can be described as: On the other hand, as a natural person, he is driven by the feelings of self-interest; And as a citizen, he 
also acts as a public duty, this kind of split between justice and self-interest is the essence of the alienation of modern human nature. Around this problem, Rousseau put forward the idea of taking moral education as the cornerstone of building a rational political community, to restore human nature in the education of civic education with a sense of social identity and high moral feelings.

Rousseau advocates the supremacy of national sovereignty; the sovereignty of the state embodies the will of the people. In the social contract theory, Rousseau advocates the protection of the interests and power of everyone through a social contract, the realization of equal freedom between people and people. He tried to design a community life under the social conventions. To regain the freedom that they had enjoyed in the state of nature, the social convention is "public opinion", mean that everyone with its full power in common under the supreme guiding public opinion, and accept each member in the community as an inseparable part of the whole; The general will as the moral foundation of the establishment of the republic, people regain freedom and equality under the guidance of the general will be the highest.

\section{The reference of Rousseau thought to the reform of citizen education in China}

Civic education is a series of educational processes to train the public to participate in the public life of the country and society. The rapid development of national economic and cultural undertakings and the promotion of the construction of political civilization, it puts forward higher and faster demands for the construction of civil society. Relatively speaking, our present society has a large gap in the quality of the public, the social participation, and the organization and management. Know the actual cause, whether it is theoretical research or educational practice, the relative lag of civic education is an important aspect, from the perspective of the richness of the connotation of civic education and the international of the effect of civic education, the present civic education in China is in a state of infamous and awkward situation, improving the understanding of the law of Education, Rousseau's idea of civic education is worth profundity analysis and creative reference.

\subsection{Basic compliance of civic education: on the premise of human natural development}

The modern society is becoming more and more aware that the democracy of the state system is not only dependent on the justice of the system, it also relies on citizens' enjoyment of rights and the "character" or citizenship of citizens, personal accomplishment has become an important factor restricting the awareness of citizens and the improvement of citizens' quality. Thus civil education should not be simply understood as moral preaching and ideological and political Sermons, it should be a systematic education process from personal knowledge, cognitive ability to comprehensive quality, this process must return to the origin of cognition and follow the basic principles of human cognitive development and education.

\subsection{The Basic Point of Practice of Civic Education: National Core Value Identification}

The transformation of civic education from "natural state" to "citizen state", the moral process of forming a "public will" must be experienced. As Rousseau in "Emile" pointed out that the cultivation of citizens on the country's overall moral identity is crucial to the moral community, this project of recourse to the human mind depends on moral education. The state is not a natural person's private collection, but the moral citizens will jointly, is based on a unified general will of the citizens of the community and moral community, any civic education should be based on the national identity of the core values.

\subsection{The Best Way of Civic Education: Moral Practice}

Rousseau advocates that a person takes part in the action of moral education from childhood and pays attention to practice rather than empty oral preaching. In a sense, morality itself is practical. It is not only in the subjective concept of human beings, but must be carried out in the behavior of the moral subject. The social behavior of man is manifested by the externalization of moral concept. Our civic education is a kind of moral education, and it should also be the process of lifelong education 
and lifelong practice, and moral practice should run through the whole life process of citizens. It depends on the organic coordination of family, school and society.

4.4 The Core Content of Civic Education: the Education of Free Concept and the Cultivation of the Plastic Ability of the Social Environment

Civil freedom is a kind of social freedom, but also a sense of freedom, more freedom to adapt to the initiative. Modern civic education advocates patriotism and public welfare, and advocates public interests.

\section{The differences between Singapore and China's Civic Education}

\subsection{The Difference between Civic Education in Singapore and the Content of Civic Education in China}

The main content of civil education in China is to emphasize the combination of Marx's theory and Chinese fine traditional morality. Taking collectivism as the core, highlighting ideological and Political Education. Require citizens to have stable, healthy political ideas and a firm socialist political direction. Attach importance to imparting the moral knowledge of the system to the students, cultivate students' moral behavior habits. The content of civic education in Singapore contains a strong individualism and utilitarianism in capitalism. Encourage individuals to stand up, compete, and make people out of dependence, development independence. Pay attention to the cultivation of moral sensitivity and moral thinking ability. Emphasis on seeking common ground for people of different races and religions, while preserving the cultural and religious characteristics of various ethnic groups, the interests of the society and the state are maintained.

\subsection{The Difference between Civic Education in Singapore and the Way of Civic Education in China}

In the way of civic education in China, school education is focused on instillation of training education, the content of national education is usually reflected only in the ideological and moral teaching materials, the development of civic education activities is often formalized, dogmatic and imperative, school moral education in Singapore is more inclined to discuss the problem. The school pays attention to infiltrating civic education through the current citizenship, history, geography and so on.

\section{Thinking and conclusion}

Citizenship education, as a social system project, requires the diversification and systematization of the implementation of civic education systematization refers to the country's design based on the top level, integrating the content of civic education into compulsory and higher education through the Department of Education, using a variety of network media, Pay special attention to online education, effective expansion of civil education and guidance in the classroom, online network and platform carrier, create a good social atmosphere within the whole society, connecting the concept of civic education to the growth of citizens, to form an Omani-directional coverage system, and supplemented by policies and regulations, ensure the long-term sustainable development of civic education, the need to complete the construction of the rule of law society. 


\section{References}

[1] GuoWang Zhang. We must defend social life: redefine the domain of Rousseau's thought [J]. Academic exchanges, 2015 (08):152.

[2] Liu Ye. Rousseau's philosophy of democracy [M]. Changchun: Jilin publishing Refco Group Ltd, 2014:212.

[3] Emile Rousseau. M. Li Pingou, translation. Beijing: People's education press, 1985.

[4] Rousseau. The theory of social contract [M]. Beijing: People's daily press, 2007.

[5] Li Bo and Jinlan Wang: "Research on tax issues of shared economic and commercial model", "Discussion on modern economy" in the fifth phase of 2016.

[6] Huasheng Zhong: Exploration of the shared economic model, Journal of Peking University (PHILOSOPHY AND SOCIAL SCIENCE EDITION), 1994 sixth phase.

[7] Fuyu lv: "the development trend of sharing the economy and the coping strategy", "business age" in the tenth phase of 2014. 